\title{
Heat Stress-induced Protein Glycosylation in Mammalian Cells
}

\author{
哺乳動物細胞において熱ストレスにより誘導されるグリコシル化について
}

\author{
Henle, Kurt J.; Jethmalani, Sunita M.; and Nagle, William A. \\ Department of Medicine, Division of Hematology/Oncology, University of Arkansas for Medical Sciences, \\ Little Rock, AR 72205-5484, USA, FAX:1-501-671-2510, E-mail: KJHenle@Life.UAMS.edu
}

Key Words: calreticulin, GP50, heat shock proteins, stress glycosylation, thermotolerance

\begin{abstract}
The cellular stress response is a model for the regulation of gene expression and represents a highly conserved mechanism for cells that respond to a changing environment. The cellular stress response includes a significant glycobiological component, which although not well characterized, appears essential and complementary to the role of "classical" heat shock proteins (HSPs). This review concentrates on the glycobio-logical component of the mammalian stress response, where several major heat stress-induced glycoproteins have been identified to date. For example, the expression and glycosyl-ation of GP50 and GP62 is associated with the development of thermotolerance, while P-SG67 and P-SG64 are glycosylated "promptly", i.e., within minutes after the initiation of heat stress. GP50 in CHO cells is homologous to the serpin familyrelated retinoic acid-inducible mouse J6 gene product, whereas P-SG67 and P-SG64 are glycosylated variants of the multifunctional ER protein, calreticulin. Potential functions for stress glycoproteins and their possible interaction with HSPs are discussed. The availability of molecular probes for stress glycoproteins should facilitate studies to understand their functions and to utilize them in biotechnological applications.
\end{abstract}

\section{A. Introduction}

Individual cells and multicellular organisms respond to heat stress with rapid and profound alterations in cell metabolism and gene expression. This dramatic response has become the focus of a new field of investigation with profound implications for basic cell physiology and biotechnology applications. Early studies concentrated almost exclusively on heat shock proteins (HSPs), their synthesis, and their mechanism of regulation in the cellular stress response. Studies on HSPs have now expanded to the extent that they are featured in several major annual reviews (Parsell 1993, Morimoto 1993, Todd 1994, Becker 1994, Lund 1994). Their role now extends well beyond heat stress to a spectrum of other physiological and non-physiological stress conditions.

The mechanisms operative in the cellular stress response appear closely related to the normal physiological pro-
要 約

ストレスに対する細胞の応答は遺伝子発現制御のモデルで あり、変化する環境に細胞が応答するために遺伝的に保存され た機構のよい例である。細胞のストレスに対する応答には、糖 鎖生物学的な因子がかなり関係している。こうした因子の性質 はよく調べられてはいないが、“古典的な”熱ショックタンパク 質(HSPs)が機能するために必要であり、HSPsの機能を補うはた らきがある。この総説は、哺乳動物のストレス応答における糖 鎖生物学的成分に焦点をあて、現在までに同定されているいく つかの主要な熱ストレス誘導糖タンパク質についてのべる。た とえば、GP50 とGP62 では遺伝子発現及びグリコシル化が熱許 容性の誘導に伴って起こるが、P-SG67 とP-SG64 の場合には“敏 速な”(すなわち、熱ストレス開始の数分内)グリコシル化が起こ る。CHO細胞のGP50は、サーピンファミリーに属するレチノー ル酸で誘導されるマウスのJ6 遺伝子産物とホモロジーがある が、P-SG67とP-SG64は多くの機能を合わせ持つERタンパク質 であるカルレチクリンのグリコシル化された変型である。この 総説では、ストレス糖タンパク質のあり得る機能とそのHSPs の関係について議論する。ストレス糖タンパク質に対する分子 プローブを用いることにより、ストレス糖タンパク質の機能を 理解する研究と、それらの糖タンパク質を生物工学に利用する ことが容易になるはずである。

\section{A. はじめに}

個々の細胞および多細胞生物は、熱ストレスに対し、細胞 の代謝と遺伝子発現を迅速かつ徹底して変化することで応答す る。この劇的な応答は、新しい研究分野の焦点となり、基礎細 胞生理学と応用生物工学に多大な影響を持つことになった。初 期の研究はほとんどすべて熱ショックタンパク質(HSPs)と、そ の生合成及び細胞ストレス応答に扔ける制御に集中した。HSPs に関する研究は、毎年いくつかの主要な総説に揭げられるまで に増大している(Parsell 1993, Morimoto 1993, Todd 1994, Becker 1994, Lund 1994)。熱ショックタンパク質は、熱ストレスだけで なく他のさまざまな生理的、非生理的ストレス状態においても 機能していることがわかってきた。

細胞のストレス応答のメカニズムは、正常な生理的過程に 扔けるタンパク質の生合成、輸送と組上げに密接に関係してい 
cesses involved in protein synthesis, transport and assembly, where most HSPs serve as important physiological catalysts (Schlesinger 1994, Hartl 1994, Stuart 1994). HSPs are also linked to the phenomenon of thermotolerance - the transient acquisition of resistance to otherwise lethal heat exposures (Henle 1978, Parsell 1993b). In spite of the great strides in defining the underlying mechanisms and functions for various HSPs, the HSP paradigm, where HSPs account for all aspects of the cellular stress response, remains incomplete. For example, cells that express high constitutive levels of a particular HSP, such as HSP70, are not always heat resistant; conversely, heat-resistant cells are not necessarily characterized by high cellular levels of HSPs, e.g., HSP70 or HSP27 (Henle 1987). Nevertheless, it appears generally true that high levels of HSPs such as HSP70, HSP27, and HSP104 appear to be capable of increasing cellular heat resistance to some extent (Parsell 1994). However, the persistent observation that cellular levels of HSPs alone do not determine cellular heat resistance, has led to the suggestion that multiple mechanisms may be responsible for expression of thermotolerance (Laszlo 1988, Lee 1988, Piper 1993). In this review, we concentrate on the role of one such mechanism, namely, protein glycosylation induced by cellular heat stress.

\section{B. Polyols}

Studies with compounds that protect cells against heat killing have provided insights into potential mechanisms of thermotolerance (Henle 1981, Henle 1987b). A small number of compounds can increase cellular resistance to high temperatures when added to culture medium in a dose-dependent manner (Henle 1987b). These "heat protectors" are generally nontoxic, and do not themselves elicit a cellular stress response, as seen for example with exposure to arsenite, diamide, or heavy metals and which leads to the development of (endogenous) thermotolerance. The presence of heat protectors is absolutely necessary during stress to achieve heat resistance. Both sugars, polyols, and their naturally occurring stereoisomers, as well as certain non-biological synthetic compounds have been included in the category of heat protectors (Henle 1985). These observations have led to the formulation of the polyol hypothesis - the proposition that carbohydrates play an important role as physiological heat protectors in cellular thermotolerance (Henle 1982).

In yeast, elevated level of the disaccharide, trehalose, appears to be the principal mechanism for elevated cellular heat resistance (De Virgilio 1990). The cellular trehalose concentration was closely correlated to thermotolerance expression, whereas, HSP70 was correlated to cellular recovery from heatstress and not directly to the expression of thermotolerance in yeast (Hottiger 1992, 1994). However, cellular trehalose levels themselves may be regulated by HSP70, and to a lesser extent
るように見える。これらの過程でほとんどのHSPは、主要な生 理的触媒としての機能を果たしている(Schlesinger 1994, Hartl 1994, Stuart 1994)。HSPsは熱許容性(致死的な熱処理に対する一 過的な抵抗性の獲得)の現象とも結びついている(Henle 1978, Parsell 1993b)。種々のHSPsの機能のメカニズムの解明が大幅に 進んできたにもかかわらず、HSPパラダイム(HSPsがあらゆる細 胞ストレス応答に関与していること)についての理解は完全では ない。たとえば、特定のHSP(HSP70)を常時高レベルで発現して いる細胞が、必ずしも常に熱抵抗性があるとは限らない。反対 に、熱抵抗性のある細胞は、必ずしも高レベルの細胞内HSPs (HSP70またはHSP27)を持つとは限らない(Henle 1987)。一般的 にいえば、高レベルのHSPs(HSP70、HSP27 そしてHSP104)は、 細胞の熱抵抗性をある程度増大させることができるようにみえ る(Parsell 1994)。しかし、HSPsの細胞内レベルは単独で細胞の 熱抵抗性を決定するわけではないという多くの観察により、熱 許容性の発現にはいくつかのメカニズムが必要なのではないか ということが示唆される (Laszlo 1988, Lee 1988, Piper 1993)。こ の総説では、我々はそのようなメカニズムの一つ、主として細 胞に対する熱ストレスにより誘導されるタンパク質グリコシル 化の機能に注目する。

\section{B. ポリオール}

熱による殺傷から細胞を保護する化合物の研究は、熱許容 性のメカニズムの理解のてがかりとなった (Henle 1981, Henle 1987b)。いくつかの化合物を培養細胞の培地に加えると、高温 に対する細胞の抵抗性が濃度依存的に増大する(Henle 1987b)。 これらの“熱保護剤”は一般的に非毒性で、それ自身は細胞ス卜 レス応答を誘導しない。これに対し、たとえば砒素化合物、ジ アミドや重金属処理は熱許容性を誘導する。熱抵抗性の発現に は、ストレスのかかっている間熱保護剤が存在することが絶対 に必要である。糖、ポリオールと自然界に存在するそれらの立 体異性体、生物体内には存在しないある種の合成化合物なと は、熱保護㶡の範疇に入る (Henle 1985)。これらの観察から、ポ リオール仮説(糖質が細胞の生理的熱許容性に重要な役割を果た している)が生まれた(Henle 1982)。

酵母に掠いては、二糖類トレハロースのレベルが上昇する ことが、細胞の熱抵抗性の上昇における基本的なメカニズムら しい(De Virgilio 1990)。細胞のトレハロース濃度は熱許容性の発 現と密接に対応している。そ机に対しHSP70は熱ストレスから の回復に対応し、熱許容性発現には直接対応してはいない (Hottiger 1992, 1994)。しかし細胞のトレハロースレベルそれ自 身はHSP70により制御されているらしい。トレハロースレベル はHSP104とHSP90によっても、HSP70より弱いが制御されてい 
by HSP104 and HSP90 (Cheng 1993). In contrast to yeast, mammalian cells do not accumulate intracellular polyols or sugars during thermotolerance (Henle 1987).

\section{Stress-induced Protein Glycosylation}

Without evidence to support the polyol hypothesis in mammalian cells, subsequent studies sought a correlation between heat stress-induced protein glycosylation and thermotolerance (Henle 1987). Covalent attachment of carbohydrates to proteins should sidestep the increased osmotic pressure that results from the accumulation of intracellular polyols, while potentially providing heat protection similar to that achieved with polyols in the microenvironment of the glycosylated protein. Motivated by such reasoning, several stress glycoproteins were identified and are now being implicated in mechanisms of cellular stress response. Moreover, an increase in the activity of several glycosyltransferases was also observed when cells recovered from heat stress and developed cellular thermotolerance (Henle 1988b, Henle 1990).

\section{C-1. GP50}

GP50 is the major stress glycoprotein induced in $\mathrm{CHO}$ cells following thermotolerance development by heat stress (Henle 1988, Fig. 1). Expression of GP50, like that of HSP70, was correlated with cellular heat resistance in $\mathrm{CHO}$ cells (Henle 1990b, Henle 1991). This protein is closely related to, or identical to gp46 (Clarke 1991), J6 protein (Wang 1990) and HSP47 (Hirayoshi 1991). GP50 has recently been identified as the homolog of the murine retinoic acid-inducible $\mathrm{J} 6$ gene product after Northern and Western blotting using J6 cDNA probe and antibodies (Henle 1994). The J6 gene is approx. 7.7 $\mathrm{kb}$ in length and contains 5 or 6 exons (Wang 1994). One of the splice sites is modified by heat, but not by other stress condi-
るらしい(Cheng 1993)。哺乳動物細胞は酵母とは異なり、熱許 容時に細胞内ポリオールや糖を蓄積しない(Henle 1987)。

C. ストレスにより誘導されるタンパク質のグリコシル化 哺乳動物細胞においてはポリオール仮説を支持する証拠は ないが、以下に述べる研究は熱ストレス誘導タンパク質のグリ コシル化と熱許容性との関連をしらべたものである(Henle 1987)。糖鎖をタンパク質と共有結合させることによって、細胞 内ポリオールが蓄積する場合に起こる浸透圧の増大を回避する ことができ、糖タンパク質の微細環境においてポリオールによ るものと似た熱保護効果が得られると考えられる。そのような 考え方から、いくつかのストレス糖タンパク質が同定された。 そしてそれらは現在、細胞ストレス応答のメカニズムに関与し ていることが示唆されはじめている。しかも、いくつかの糖転 移醇素活性の上昇が、熱ストレスから回復し細胞の熱許容性が 発達した細胞に揖いて観察された(Henle 1988b, Henle 1990)。

\section{C-1. GP50}

GP50はCHO細胞で誘導される主要なストレス糖タンパク 質で、熱ストレスにより熱許容性が発達したあとで誘導される (Henle 1988,図1参照)。CHO細胞におけるGP50の発現はHSP70 のように細胞の熱抵抗性に対応する(Henle 1990b, Henle 1991)。 このタンパク質はGP46 (Clarke 1991)、J6タンパク質(Wang 1990) そしてHSP47(Hirayoshi 1991)と密接に関連があるか、またはを れらと同じものである。GP50は、J6cDNAプローブと抗体を用 いたノーザン及びウエスタンブロッテイングにより、マウスの レチノール酸誘導遺伝子産物のホモローグとして同定された (Henle 1994)。J6 遺伝子は $7.7 \mathrm{~kb}$ の長さで 5〜6のエキソンを含 む(Wang 1994)。スプライシングの起こる部位の一つは、熱によ

Fig. 1. Heat-induced protein glycosylation in three mammalian cell lines. Three representative cell lines, including Chinese hamster ovary (CHO), human mammary carcinoma, MCF7, and Syrian hamster duct deferens DDT1 cells were grown under identical culture conditions and heated in a water bath either at $37^{\circ} \mathrm{C}(\mathrm{C})$, or at $45^{\circ} \mathrm{C}$ for $10 \mathrm{~min}(\mathrm{~h})$. After $5 \mathrm{~h}$ at $37^{\circ} \mathrm{C}$ incubation for thermotolerance development, cells were labeled for $1 \mathrm{~h}$ at $37^{\circ} \mathrm{C}$ with $\mathrm{D}-\left[2-^{-3} \mathrm{H}\right]$ mannose $(50$ $\mu \mathrm{Ci} / \mathrm{ml}$ ), washed, and scraped as previously described (Henle 1988). Cell proteins were analyzed by SDS-PAGE after separation into soluble (Cy) and insoluble (nuclear: $\mathrm{Nu}$ ) fractions; gel lanes were loaded with equal amounts of radioactivity. In the fluorogram presented here, molecular weight markers are indicated on the left side; the arrow on the right side indicates the position of GP50, the $50 \mathrm{kDa}$ protein, whereas, the arrow on the left side indicates the position of GP62, the $62 \mathrm{kDa}$ protein. GP62 is especially prominent in cytosol of $\mathrm{CHO}$ and MCF-7 cells. 
tions, and increases the mRNA in the non-coding region (Takechi 1994). The 5'-flanking region features a potential heat shock element and a binding site for the GATA- 1 and GATA-2 transcription factors (Wang 1994). Specific functions for J6 protein have not been identified, but J6 is a member of the serpin (serine protease inhibitor) protein family; however, it lacks the active site of a typical protease inhibitor. The serpin family proteins are involved in multiple regulatory functions that include protein folding, extracellular matrix remodeling, and cell differentiation (Potempa 1994). HSP47, the probable chicken homolog of $\mathrm{J} 6$, has been implicated in a collagen-specific chaperone function (Takechi 1992, Natsume 1994).

\section{C-2. GP62}

GP62 is a less prominent stress glycoprotein that appears in $\mathrm{CHO}$ cells after thermotolerance induction by heat stress. However, this protein also occurs in other cell lines (Fig. 1 ); in some cases, it was the major stress glycoprotein while GP50 was the less prominent stress glycoprotein. One such example is the rodent cell line, M21, derived from the parental cell line, Rat-1. M21 was modified to stably overexpress the human HSP70 ( $\mathrm{Li} 1991$ ); simultaneously, M21 cells exhibited a high level of constitutive heat resistance, but with no loss of their capacity for further thermotolerance development following heat conditioning. The heat resistant phenotype of M21 cells was attributed to the overexpression of HSP70 because no other modifications were noted in the protein synthesis profile (Li 1991). However, recent studies from our laboratory have demonstrated concurrent changes in heat stress-induced protein glycosylation in M21 cells (Henle 1995). Specific glycosylation of GP62 was increased in the heat-resistant M21 cells when compared with Rat-1 cells, which was further enhanced in both Rat-1 and M21 cells with thermotolerance development. Thus, GP62 glycosylation correlated directly with cellular heat resistance (Henle 1995). These changes occurred in parallel with the expression of HSP70, indicating that stressinduced protein glycosylation is a significant component of cellular stress response. Whether stress glycoproteins act through independent or cooperative mechanisms with HSPs remains to be determined (see hypotheses below). GP62 has recently been purified and is being identified by microsequencing (Jethmalani, unpublished).

As in CHO cells, GP62 appeared clearly visible in human mammary carcinoma, MCF7, and the Syrian hamster duct deferens cells, DDT1, but was a less prominent stress glycoprotein (Fig.1). Glycosylation of GP50 was also increased in both cytosol and nuclear fractions after thermotolerance induction in all three cell lines studied (Fig. 1). In comparison to GP50, the less prominent glycosylation of GP62, the second heat-induced glycoprotein, appeared to be increased mostly in the cytosol of $\mathrm{CHO}$ and MCF7 cells with minor increases in the nuclear fraction. Thus, stress-induced glycosylation of GP50 and GP62 is a
り変化を受けるが他のストレス条件によっては受けず、非転写 領域のmRNAが増大する(Takechi 1994)。5'隣接領域は潜在的熱 ショック配列を持ち、GATA-1 とGATA-2の転写因子結合部位を 持つ(Wang 1994)。J6タンパク質に特異的な機能は同定されてい ないが、J6はサーピンファミリー(セリンプロテアーゼインヒビ ター)の一員である。しかしプロテアーゼインヒビターに典型的 な活性部位は欠如している。サーピンファミリータンパク質 は、タンパク質の折り畳み、細胞外マトリックスの再構築、そ して細胞分化などの、多くの制御機能に関与している (Potempa 1994)。HSP47はニワトリのJ6ホモログである可能性があり、コ ラーゲンに特異的なシャペロン機能が示唆されている(Takechi 1992, Natsume 1994)。

\section{C-2. GP62}

GP62はGP50よりは量の少ないストレス糖タンパク質で、 CHO細胞内に打いて熱ストレスによる熱許容性の誘導後あらわ れる。しかしこのタンパク質は他の細胞系統においてもみられ (図1)、GP50が量の少ないストレス糖タンパク質である場合、主 要なストレス糖タンパク質であることもある。そのような例の 一つは、Rat-1 親細胞系列に由来する踾歯類細胞系統M21であ る。M21をヒトHSP70を安定に過剩発現するように変化させる と(Li 1991)、M21細胞は高レベルの熱抵抗性を示した。しかし 熱処理後に熱許容性を発達させる能力は失われなかった。M21 の熱抵抗性という表現型はHSP70の過剩発現によるものとされ ている。なぜならタンパク質合成パターンにおいて他のタンパ ク質の変化は観察されなかったからである(Li 1991)。しかし、 近年我々の研究室では、M21細胞において、熱ストレスにより 誘導されるタンパク質のグリコシル化がHSP70の過剩発現に 伴って変化することが示された (Henle 1995)。熱抵抗性M21変異 細胞におけるGP62の特異的グリコシル化は、Rat-1細胞にくらべ 増加し、熱許容性の発達にともなって、Rat-1 と M 21 細胞両方に おいてさらに増大した。このようにGP62のグリコシル化は細胞 の熱抵抗性に直接対応した(Henle 1995)。これらの変化はHSP70 の発現に平行して起こり、このことは、ストレスにより誘導さ れるタンパク質のグリコシル化は、細胞のストレス応答の重要 な部分であることを示している。ストレス糖タンパク質が独立に 働くかHSPと共同したメカニズムで働くかは今後の研究に待た权 ばならない(下記の仮説参照)。GP62は近年精製され、マイクロシー ケンシングによりその同定が進行中である(Jethmalani,未発表)。

GP62は、CHO細胞と同様にヒト乳癌MCF7とシリアンハム スタ一輸送管細胞 DDT1においても、明瞭に発現しているのが 認められるが、ストレス糖タンパク質に占める割合はそう高く ない(図1)。これら三つの細胞系すべてにおいて、GP50のグリコ シル化も、熱抵抗性の誘導に伴って細胞質と核画分の双方で起 こることが認められている(図1)。こうしたGP-50の挙動に比べ ると、第二の熱誘導糖タンパク質であり、量的にもあまり多く ないGP62のグリコシル化は、主としてCHOとMCF7細胞の細胞 質で増加しているように見え、核画分での増加はこれに比べ ずっと少ないようである。このようにストレスにより誘導され るGP50 とGP62のグリコシル化は、HSP70の発現と同様、他の面 
highly conserved feature, like the appearance of HSP70, in otherwise unrelated mammalian cell lines. The conserved nature of GP50 and GP62 glycosylation is in contrast to the variability that occurs during "prompt" stress glycosylation (see below).

\section{C-3. P-SG67 and Calreticulin}

Acute heat stress conditions induce a novel type of protein glycosylation that is distinct from stress glycosylation in thermotolerant cells, discussed above. Heat stress at $43^{\circ} \mathrm{C}$, or higher, results in a profound inhibition of general protein glycosylation in mammalian cells. However, residual glycosylation becomes highly selective and results in the glycosylation of the so-called "prompt" stress glycoproteins (Henle 1993). The "prompt" glycosylation phenomenon was observed during acute heat stress episodes as short as $10 \mathrm{~min}$ at $45^{\circ} \mathrm{C}$. Glycosylation increased in a dose-dependent manner up to $60 \mathrm{~min}$ at $45^{\circ} \mathrm{C}$. Interestingly, prompt glycosylation was observed even in the presence of cycloheximide which suggests that glycosylation occurred on mature proteins (Henle 1993). Prompt glycosylation does not appear to correlate with cellular heat resistance, in contrast to glycosylation of GP50 and GP62.

P-SG67 is the major "prompt" stress glycoprotein in $\mathrm{CHO}$ cells and has been recently identified as calreticulin using microsequencing techniques (Jethmalani 1994b). P-SG64, the secondary "prompt" stress glycoprotein in these cells, was also found to be identical to calreticulin (Jethmalani 1994b). Thus, calreticulin is a stress glycoprotein that appears to be variantly glycosylated during "prompt" heat stress. The two glycosylated forms of calreticulin had similar calcium binding properties (Jethmalani 1994a, 1994b) as the unglycosylated protein (Michalak 1992). Prompt glycosylation of P-SG67/P-SG64/ calreticulin was not affected when the heat-induced intracellular rise in calcium was blocked by chelation with the calcium chelator BAPTA (Jethmalani 1994a). The reason for a variable glycosylation status of calreticulin, and its function in the heat damaged cells is unknown, but is probably not related to calcium homeostasis.

Calreticulin is usually resident in the endoplasmic reticulum (ER), and is closely related to calnexin (Bergeron 1994). Calnexin also shares significant partial homology with P-SG67 (Jethmalani 1994b). Calnexin is known to perform chaperone functions like HSPs, but within the hydrophobic membrane milieu, where hydrophilic HSPs have limited access (Ou 1993). The observation that HSP70 contains a calmodulin binding domain (Stevenson 1990) which is highly conserved in a variety of organisms, suggests that these chaperones do not function as single agents, but could interact with calcium or calcium-binding proteins like calreticulin and calnexin. The latter concept is reinforced by a recent study where affinity columns were constructed with various unrelated denatured proteins (histones, gelatin, $\alpha$-fetoprotein, IgG, etc.); these columns bound seven ER proteins that were specifically eluted with ATP. The
では相互に関係のない哺乳細胞系統間で非常によく保存された 現象といえる。GP50とGP62のグリコシル化がよく保存された現 象であるという性質は、以下に述べる、“敏速な”ストレス応答 グリコシル化が変化に富んでいるのとは対象的である。

\section{C-3.P-SG67とカルレチクリン}

急性の熱ストレス状態は新しいタイプのタンパク質のグリ コシル化を誘導するが、それは上に述べた熱許容性を獲得した 細胞におけるストレスグリコシル化とは決定的に異なってい る。 $43^{\circ} \mathrm{C}$ 及びそれ以上の熱ストレスは、哺乳動物細胞において 通常のタンパク質グリコシル化を強く阻害する。しかし残存グ リコシル化活性は高度に選択的になり、“敏速な”ストレス糖夕 ンパク質とよばれるタンパク質群のグリコシル化が行われる (Henle 1993)。この“敏速な”グリコシル化現象は、10分、 $45^{\circ} \mathrm{C}$ と いうょうな短い急性の熱ストレス過程中で観察される。このグ リコシル化は $45^{\circ} \mathrm{C} て ゙ 60$ 分までの間、時間依存的に増加する。面 白いことに、この敏速なグリコシル化はシクロヘキシミド存在 下でも観察される。このことはこのグリコシル化が成熟タンパ ク質に対して起こることを示唆している(Henle 1993)。敏速なグ リコシル化はGP50とGP62のグリコシル化の場合とは異なり、細 胞の熱抵抗性とは対応していないようにみえる。

P-SG67はCHO細胞における最大の“敏速な”ストレス糖タン パク質であり、近年マイクロシーケンス法によりカルレチクリ ンであることが同定された(Jethmalani 1994b)。P-SG64はこの細 胞の第二の“敏速な”ストレス糖タンパク質であるが、これもや はりカルレチクリンと同一分子であることが明らかになった (Jethmalani 1994b)。このようにカルレチクリンはストレス糖夕 ンパク質であり、“敏速な”熱ストレス過程で変化に富むグリコ シル化を受けているように見える。カルレチクリンのこの二つ のグリコシル化型は(Jethmalani 1994a, 1994b)グリコシル化さ机 ていないものと似たカルシウム結合能を持つ(Michalak 1992)。 P-SG67/P-SG64/カルレチクリンの敏速なグリコシル化は、熱に より誘導される細胞内カルシウムの上昇を、カルシウムキレー ターBAPTAによるキレーションによりブロックしても影響を受 けない(Jethmalani 1994a)。カルレチクリンにいろいろなグリコ シル化状態がある理由、そして熱による損傷を受けた細胞にお けるカルレチクリンの機能は不明であるが、カルシウムホメ才 スタシスとは関係ないと考えられる。

カルレチクリンは普通ERに存在し、カルネキシンと密接な 関係がある (Bergeron 1994)。カルネキシンはP-SG67ともかなり の量の部分的ホモロジーを持つ(Jethmalani 1994b)。カルネキシ ンはHSPと同様シャペロン機能を持つことが知られているが、 親水性のHSPが近づきにくい疎水的な膜環境において機能して いる(Ou 1993)。多くの生物でHSP70がカルモジュリン結合ドメ インを持つという観察は (Stevenson 1990)、これらのシャペロン は単一の作用物として機能するのではなく、カルレチクリンや カルネキシンと同様、カルシウムやカルシウム結合タンパク質 と相互作用する可能性を示唆している。この後者の概念は、い ろいろな変性タンパク質(ヒストン、ゼラチン、 $\alpha$ ーフェトタンパ ク質、 $\mathrm{IgG}$ な゙)を固定化したアフィニテイーカラムを用いた研 究により補強された。7つのERタンパク質がこれらのカラムに 
bound ER proteins included Grp78 (the ER chaperone, BiP), Grp94, calreticulin, an unidentified $46 \mathrm{kDa}$ protein, and $3 \mathrm{mem}-$ bers of the thioredoxin family (protein-disulfide isomerase, ERp72 and P50). Release of bound proteins was $\mathrm{Ca}^{2+}$-dependent suggesting that these proteins belonged to a class of $\mathrm{Ca}^{2+}$ dependent chaperones (Nigam 1994). Although present models of the stress response do not integrate the heat-related HSP and glycosylation phenomena in a comprehensive molecular concept, observations such as those above, suggest that the stress response requires the coordinated interplay of heat-induced $\mathrm{Ca}^{2+}$ fluxes, HSP mobilization, HSP redistribution, calreticulin modification, and protein glycosylation. The net effect of these various stress response elements could result in the expression of stress resistance and enhanced recovery from cell injury.

Prompt glycosylation of calreticulin exhibits an unusual degree of variability within the same cell line in spite of identical growth conditions and heating protocols. This is shown in Fig. 2 where CHO cells were identically heated in separate experiments and demonstrated similar glycosylation patterns for the corresponding unheated control cells. The glycosylation pattern in panel $\mathrm{A}$ is the most common one; nevertheless, glycosylation patterns shown in panels $B$ and $C$, though less common also appeared under apparently identical experimental conditions. This variability is in sharp contrast to the invariant glycosylation patterns for GP50 and GP62 which remain con-
吸着し、ATPにより特異的に溶出された。結合したERタンパク 質はGrp78(ERシャペロン、BiP)、Grp94、カルレチクリン、未知 の $46 \mathrm{kDa}$ タンパク質とチオレドキシンファミリーに属する三つ のタンパク質(タンパク質ジスルフィドイソメラーゼ、 ERp72,P50)である。結合したタンパク質の溶離は $\mathrm{Ca}^{2+}$ 依存性で あり、このことはこれらのタンパク質はCa ${ }^{2+}$ 依存性シャペロン に属することを示唆している (Nigam 1994)。現在のストレス応 答モデルは、熱関連HSPとグリコシル化現象を全体的な分子的 概念として包括してはいない。しかし上記のような観察によ り、ストレス応答には、熱により誘導されるCa ${ }^{2+}$ の流れ、HSPの 移動、HSPの再分布、カルレチクリンの修飾、そしてタンパク 質のダリコシル化の協調的な相互作用が必要であることがわか る。これらのいろいろなストレス応答因子の作用が集まって、ス トレス抵抗性の発現と、細胞傷害からの速い回復が行われる。

カルレチクリンの敏速なグリコシル化は、同一系統の細胞 考、同一条件で生育し、同一条件で熱処理した場合でも、幅広 い変化を示す。図2はこのような状況を示したものである。お のおの独立した実験において、CHO細胞を同一条件で加熱し、 末処理のコントロール細胞と比べると、それぞれに対応したグ

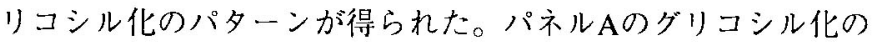
パターンは最もよくみられるものである。パネルBとCのグリコ シル化パターンはあまりみられないが同一実験条件下で見られ たものである。(敏速なグリコシル化の場合に見られる)この幅広 い変化は、相互に関係のない哺乳類細胞系統においても同一の グリコシル化のパターンを示すことが認められたGP50 やGP62
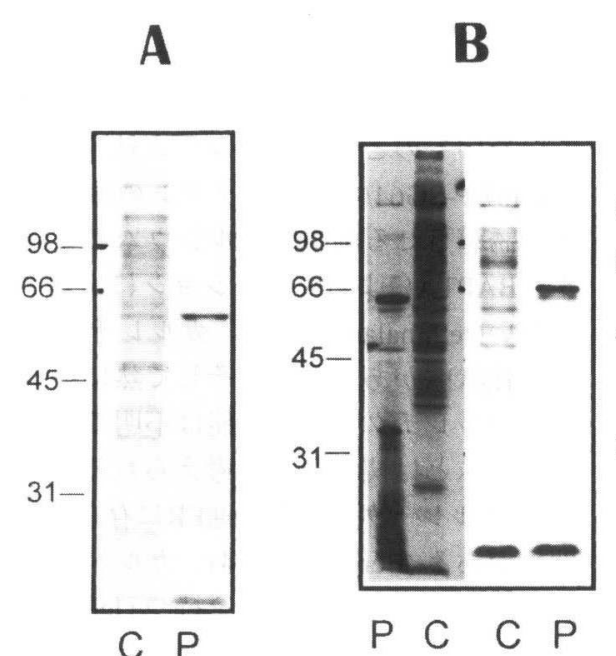

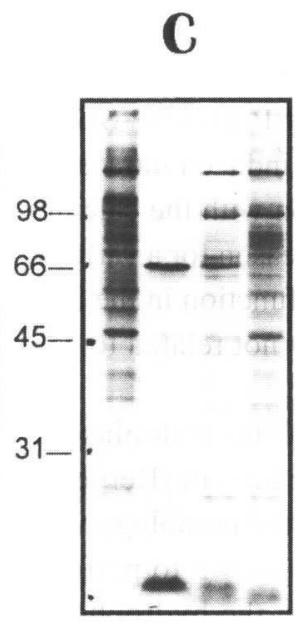

C P P C

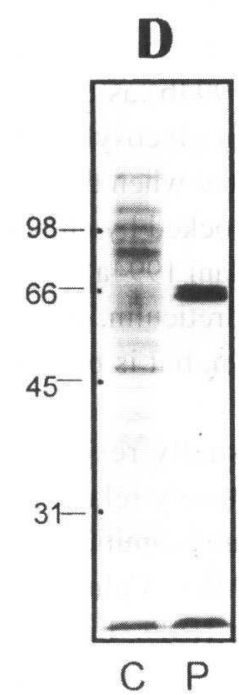

Fig. 2. Variability in prompt glycosylation during heat shock in CHO cells. This figure illustrates the variability in prompt glycosylation that can occur under identical growth and heat shock conditions within the same cell line. Each panel shows glycosylation patterns in parallel lanes for unstressed control cells and heat-stressed cells, labeled for $30 \mathrm{~min}$ at $45^{\circ} \mathrm{C}$. Molecular weight markers are shown on the left side of each panel. Panel A shows prompt glycosylation of P-SG62. In panel B, the extreme left lane shows prompt glycosylation of P-SG64, whereas, the extreme right lane shows the variable prompt glycosylation of P-SG67 and P-SG64. In panel C, the second lane shows prompt glycosylation of P-SG67, whereas, the third lane shows the variability in prompt glycosylation after treatment with Brefeldin A (Henle 1993). Panel D shows prompt glycosylation of both P-SG64 and P-SG67, similar to cells that are heated more severely (Henle 1993). In all panels, labeling of control cells is comparable to each other. $\mathrm{C}=$ Control cells and $\mathrm{P}=$ "Prompt" heat-stressed cells. P-SG67 was the most commonly glycosylated prompt stress glycoprotein. 
stant even in unrelated mammalian cell lines (Fig. 1). Nevertheless, the variable glycosylation patterns for prompt glycosylation appear to always involve calreticulin and may reflect its post-translation processing during its translocation within the ER membrane (Doms 1993).

\section{C-4. Glycosylation and Other Stress Conditions}

Stress conditions other than hyperthermia can also induce a cellular stress response. These conditions include exposures to arsenite, heavy metals, thiol-reactive agents, agents that perturb glucose metabolism (e.g., 2-deoxy-D-glucose, tunicamycin, and glucose starvation), calcium ionophores, and hypoxia (Lee 1992, Parsell 1994, Schlesinger 1994). The nonheat induced stress response caused by arsenite and hypoxia leads to upregulation of J6/GP50 (Henle 1994). Specific stressinducing agents exhibit characteristic induction efficiencies for various HSPs, GRPs, and for GP50/J6 as well. The concurrent induction of stress proteins and stress glycoproteins, though complex, supports the concept of an integrated stress response pattern.

The relationship between cellular stress and protein glycosylation is further supported by observation of GRP94 (glucose-regulated protein, $\mathrm{M}_{\mathrm{r}}$ of 94,000) induction under conditions that disrupt glucose metabolism (Lee 1992). GRP94 induction is very sensitive to agents such as tunicamycin, the calcium ionophore A23187, and amino acid analogs, although it is not significantly induced by heat stress (see Fig. 1). GRP94, like GP50, is a glycoprotein. Its normal glycosylation site is Asn-196, while three other potential glycosylation sites normally remain open. When GRP94 was overexpressed in transient expression studies with COS cells, a fraction of the expressed murine GRP94 was more highly glycosylated than endogenous, constitutive GRP94 (Qu 1994). Analysis of glycosylation via site-directed mutagenesis showed that this type of hyperglycosylation of GRP94 was directly related to the level of GRP94 expression and occurred at acceptor sites downstream from Asn-196 towards the carboxy-terminal region of the protein. Thus, the extent of GRP94 glycosylation is regulated by the level of its protein expression which further supports the concept that stress glycosylation is an integral part of cellular stress response.

Stress-induced glycosylation can also occur on molecules other than proteins and which may be intermediates in the protein glycosylation pathway. For example, arsenite, heavy metals, and thiol-reactive agents greatly increased D-[2${ }^{3} \mathrm{H}$ ]mannose radiolabeling of lipid-linked oligosaccharides. These oligosaccharides were designated M14 ( $\mathrm{M}_{\mathrm{r}}$ of 14,000) and had short half lives of 15 min, typical of other oligosaccharide lipid-linked intermediates (Niewiarowska 1987). It is possible that heat stress can cause a similar increase in radiolabeling of M14 oligosaccharides, and that M14 may participate in the glycosylation of GP50 and P-SG67 (Henle 1993).
に比べて(図 1参照)極めて対照的である。その一方で、敏速なグ リコシル化の幅広いグリコシル化パターンは、常にカルレチク リンが関与しているようにみえるが、これはこのタンパク質が 翻訳後にER膜内を移動する過程においてプロセッシング(グリコ シル化)を受けていることを反映しているらしい(Doms 1993)。 C-4. グリコシル化と他のストレス条件

高熱以外のストレス条件も細胞ストレス応答を誘導でき る。砒素化合物、重金属、チオール反応物質、グルコース代謝 を変化させる試薬(2-デオキシ-D-グルコース、ツニカマイシン、 グルコース飢餓)、カルシウムイオノフォア、酸素欠乏症などが それである (Lee 1992, Parsell 1994, Schlesinger 1994)。砒素と酸 素欠乏症により起こる非熱誘導性ストレス応答はJ6/GP50の上昇 を起こす (Henle 1994)。それぞれのストレス誘導試薬は、種々の HSPs、GRPs とGP50/J6などに対して特徵的な誘導効率を示す。 ストレスタンパク質とストレス糖タンパク質が同時に誘導され る現象は複雑であるが、ストレス応答反応が相互に関係してい るという概念を支持する。

細胞ストレスとタンパク質のグリコシル化の関係は、グル コース代謝を破壊する条件下でGRP94(グルコースにより制御さ れるタンパク質、分子量94,000)が誘導されるという観察によりさ らに支持された(Lee 1992)。GRP94の誘導は、ツニカマイシン、 カルシウムイオノフォア A23187 そしてアミノ酸アナログのよ うな試薬に非常に敏感であるが、しかし熱ストレスによっては 特に誘導は見られない(図1参照)。GRP94はGP50のように糖タン パク質で、その正常なグリコシル化部位はAsn-196であるが、他 の三つの潜在的グリコシル化部位は普通グリコシル化されてい ない。GRP94がCOS細胞で一過性の過利発現をすると、発現し たマウスGRP94は、内在性の常時存在するGRP94より高度にグ リコシル化されている(Qu 1994)。部位特異的突然変異誘発によ るグリコシル化の分析により、このタイプのGRP94の過㮃グリ コシル化はGRP94の発現レベルに直接関連しており、Asn-196か らC末方向の下流にあるアクセプター部位で起こる。このように GRP94のグリコシル化は、そのタンパク質の発現レベルにより 制御されるが、このことはストレスによるグリコシル化が細胞 ストレス応答の欠かせない要素であるという概念を支持するもの である。

ストレスにより誘導されるグリコシル化は、タンパク質の グリコシル化経路の中間体と考えられるタンパク質以外の分子 に対しても起こる。たとえば砒素化合物、重金属、チオール反 応性物質は、D-[2-3 H]マンノースの脂質結合オリゴ糖への取り込 みを大幅に増大させる。これらのオリゴ糖はM14(分子量14,000) と名付けられ、オリゴ糖脂質結合中間体に典型的な15分という 短い半滅期を持つ(Niewiarowska 1987)。熱ストレスはこれと同 様にM14オリゴ糖のラベルの増大をもたらす可能性があり、ま たこのM14オリゴ糖はGP50とP-SG67のグリコシル化に関与して いる可能性が考えられる (Henle 1993) 


\section{Distribution of Stress Glycoproteins}

Some HSPs are known to undergo a dramatic cellular redistribution following heat stress; for example, HSP70 typically translocates from cytoplasm to the nucleolus, where it is thought to facilitate nucleolar recovery (Laszlo 1992). Similarly, cellular distribution of stress glycoproteins was also altered following heat stress. The ER and the Golgi apparatus are the common sites where glycosylation and post-glycosylation events occur; nevertheless, GP50, GP62, and P-SG67 were not confined to these organelles, but were redistributed to other subcellular compartments following heat stress (Jethmalani, unpublished data). With an increase in recovery time after heat stress, stress glycoprotein redistribution changed in a manner that was characteristic for each stress glycoprotein. For example, glycosylated P-SG67 rapidly disappeared from the ER fraction after heat stress and was high in the cytosolic fraction at $6 \mathrm{~h}$ post-heating. In contrast, glycosylated GP50 was virtually unchanged with time after heat shock and appeared in the cytosolic fraction only at $18 \mathrm{~h}$ after heating. Glycosylated GP62 disappeared almost completely from all subcellular fractions by $18 \mathrm{~h}$ and appears to have a much shorter half life than GP50 (Jethmalani, unpublished data). These data suggest that each stress glycoprotein has specific roles within subcellular compartments to facilitate cellular recovery from heat stress.

\section{E. Potential Functions of Stress-induced Protein Glycosyl- ation}

The simultaneous appearance of both stress-induced protein glycosylation and enhanced HSP accumulation after heat stress is supported by numerous studies. Several viable hypotheses, discussed below, provide a conceptual framework for the role of protein glycosylation in the cellular stress response and its interaction with HSPs. Alternatively, it has been argued that stress-induced protein glycosylation may be nonspecific, reflecting random cellular injury analogous to that observed during non-enzymatic glycosylation of serum and cell proteins in the diabetic state marked by elevated glucose concentrations. The latter view, however, does not explain the selectivity of the glycosylation events and the virtually universal appearance of stress glycosylation in mammalian and perhaps other cells as well. These patterns are consistent with biological purpose and function. This concept of biological function for stress glycosylation is further supported by the parallel concepts underlying the polyol hypothesis for thermotolerance in yeast and its growing experimental support (De Virgilio 1990, Hottiger 1994). The following four principal hypotheses provide concepts, partial experimental support, and future directions for investigating specific mechanisms by which stress-induced protein glycosylation mediates the stress-resistant phenotype.

\section{D. ストレス糖タンパク質の分布}

いくつかのHSPは熱ストレスを受けると劇的な細胞内分布 の変化を示す。たとえばHSP70は（熱ストレス下で）多くの場 合、細胞質から仁へ移動するが、そこでは核小体の回復を助け るといわ札ている(Laszlo 1992)。同様にストレス糖タンパク質の 細胞内分布も、熱ストレスを受けると变化する。ERとゴルジ体 はグリコシル化とグリコシル化後のいろいろな修飾が起こる場 だが、GP50、GP62とP-SG67はこれらの細胞内小器官にとどま らず、熱ストレスを受けると他の細胞内コンパートメントに再 分布する(Jethmalani、未発表)。熱ストレスからの回復時間の経 過とともに、ストレス糖タンパク質の再分布は、各ストレス糖 タンパク質に特徽的な形でおこる。たとえばグリコシル化され たP-SG67は熱ストレスをうけると急速にER画分から失われ、熱 処理6時間後に細胞質画分で上昇する。それに対しグリコシル化 されたGP50は、熱ショックを受けた後も少しも変化せず、熱処 理18時間後でやっと細胞質画分に現れる。グリコシル化した GP62は18時間後にはほとんど完全に全細胞画分より失われ、 GP50より短い半減期を持つようにみえる(Jethmalani、未発表)。 これらのデータは、おのおののストレス糖タンパク質は各細胞 内コンパートメントにおいて熱ストレスからの細胞の回復を容易 にするための特異的な役割を持つことを示唆する。

\section{E. ストレス誘導性のタンパク質グリコシル化のあり得る機能}

ストレス誘導性のタンパク質グリコシル化と熱ストレスに よるHSP蓄積の増加が同時に起こることは、多くの研究により 支持されている。下記のいくつかの仮説は細胞ストレス応答と HSPとの相互作用におけるタンパク質のグリコシル化の役割の 概念的枠組みを与える。別の考え方として、ストレス誘導性の タンパク質グリコシル化は非特異的であって、糖尿病における グルコース濃度の上昇による血漿と細胞タンパク質の非酵素的 グリコシル化にみられるようなランダムな細胞の傷害を反映し たものだともいわれる。しかし後者の観点はグリコシル化が選 択的に起こることや、ストレスによるグリコシル化が哺乳類細 胞でもその他の細胞でもほとんど普遍的に起こることの説明に はなっていない。ストレスによって誘導されるグリコシル化の パターンは生物学的目的と機能に一致している。このストレス 誘導性グリコシル化が生物学的に機能を果たしているという概 念は、これと軌を一にする概念である、酵母における熱許容性 のポリオール仮説の基盤となる考え方およびそれに対する実験 的裏付けの堌大によりさらに支持されている(De Virgilio 1990, Hottiger 1994)。下記の四つの基本的な仮説は、グリコシル化が ストレス抵抗性表現型をつくりだす特異的なメカニズムを研究 するための概念とそれに対する部分的な実験的根拠、および将 来の方向を与えるものである。 
Antiaggregation hypothesis. Stress-induced glycosylation prevents non-specific and irreversible aggregation of the type that is associated with inter-protein disulfide bond formation.

Support for this hypothesis derives from studies with virally infected cells, where inhibition of protein glycosylation resulted in the aggregation of viral glycoproteins - this aggregation occurred within less than $1 \mathrm{~min}$ after protein release from polysomes and was accompanied by the formation of aberrant interchain disulfide bonds that stabilized the non-specific aggregation complex (Marquardt 1992). Protein aggregation was partially reversible, probably through the action of enzymes, such as protein disulfide isomerase (PDI) which is weakly inducible by cellular stress (Dorner 1990). PDI is an ER resident protein, involved in native disulfide bond formation during and shortly after translocation of secretory proteins into the ER (Freedman 1989). PDI also increases the rate of formation of disulfide bonds, and thus can catalyze the rearrangement of non-native bonds in reduced and denatured proteins in vitro (Freedman 1989). Also of interest is a recent report of protein disaggregation mediated by HSP104, which confers heat resistance to yeast cells (Parsell 1994). Of all the available protein disaggregation mechanisms, the glycosylation of native viral proteins to prevent aggregation is probably the most energyefficient process for cells at risk for injury (Marquardt 1992).

Modulation of interactions with chaperones. Stress-induced glycosylation modifies the interaction of proteins with molecular chaperones.

This hypothesis is supported by the observation that glycosylation of invertase prevented its association with the molecular chaperone, GroEL (Kern 1992). Such a mechanism might be useful under certain stress conditions when association of denatured proteins with chaperones is disadvantageous to cells. For example, impaired energy metabolism and reduced cellular ATP levels can activate a stress response in kidney cells (VanWhy 1994). However, the association of partially denatured proteins with molecular chaperones may be non-productive under conditions of low cellular ATP, because the binding and dissociation cycle of the chaperone complex is ATP-dependent (Hartl 1994). The formation of protein-chaperone complexes in those cells would prevent natural refolding (not mediated by chaperones) of partially denatured proteins, and could be catastrophic if such unproductive associations between proteins and chaperones continued to persist for the duration of cellular stress. We hypothesize that under similar stress conditions, glycosylation represents an alternate mechanism (probably ATP-independent) that could facilitate cellular recovery from the energy-deprived state by preventing proteinchaperone interactions.

\section{Chaperone functions related to specific subcellular com-}

partments. Glycoprotein chaperones may be required in subcellular compartments where classical HSPs have limited ac-
抗凝集仮説 ストレスにより誘導されるグリコシル化は、タン パク質間S-S結合形成を伴うようなタイプの非特異的な不可逆的 凝集を阻止する。

この仮説に対する支持は、ウイルスに感染した細胞の研究 に挍いて、糖タンパク質のグリコシル化の阻害がウイルス糖夕 ンパク質の凝集を起こすという知見から得られた。この凝集は タンパク質がポリソームをはなれた一分以内に起こり、異常な 鎖間S-S結合形成を伴う。このS-S結合形成は非特異的な凝集複 合体を安定化する(Marquardt 1992)。このタンパク質の凝集は部 分的に可逆的であったが、これは掞そらく、細胞ストレスによ り弱く誘導されることが知られている夕ンパク質ジスルフィド イソメラーゼ(PDI)のような酵素(Dorner 1990)の働きによるもの と考えられる。PDIはERに存在するタンパク質で、分泌タンパ ク質がERに運搬されたすぐ後や、その間のS-S結合形成に関与 している(Freedman 1989)。PDIはまたSS結合の形成速度を上昇 させるが、還元され変性したタンパク質中でこの作用によって 非正常型のSS結合を in vitroで再構成することができる(Freedman 1989)。さらに面白いのは、HSP104はこのタンパク質凝集の解 離を助け、酵母細胞に熱抵抗性を与えるという最近の報告であ る(Parsell 1994)。すべてのタンパク質凝集を阻止する、あるい は解離するメカニズムの中で、グリコシル化することによりウ イルスタンパク質の凝集が阻止する機構は、傷害を受ける可能 性のある細胞にとって多分もっともエネルギー効率のよいものな のであろう (Marquardt 1992)。

シャペロンとの相互作用を変化させる機能 ストレスにより誘 導されるグリコシル化はタンパク質と分子シャペロンの相互作 用を変化させる。

この仮説は、インベルターゼのグリコシル化がインベル ターゼが分子シャペロンGroELと結合するのを阻止するという 観察によって支持されている(Kern 1992)。そのような機構は、 変性タンパク質とシャペロンとの結合が細胞にとって不利であ る場合のようなある種のストレス条件下では有用であろう。例 えば、エネルギー代謝系の損傷と細胞内ATPレベルの低下は、 腎細胞においてストレス応答を活性化することができる (VanWhy 1994)。しかし部分的に変性したタンパク質と分子シャ ペロンとの結合は、細胞内ATPレベルが低下している条件下で は非生産的である。なぜならシャペロン複合体の結合と解離の サイクルはATP依存的であるからである(Hartl 1994)。これらの 細胞に拄けるタンパク質-シャペロン複合体形成は、部分的に変 性したタンパク質がシャペロンによらずに自然に再び折り畳ま れるのを阻止するかもしれない。そしてもしそのようなタンパ ク質とシャペロンの非生産的結合が、細胞がストレスにさらさ れている過程で続くとしたらこれは致命的である。我々はこの ようなタイプのストレス条件下では、グリコシル化がタンパク 質-シャペロン相互作用を妨げることにより、細胞がエネルギー 不足の状態から回復するための別の機構を提供しているという 仮説を考えている。

特定の細胞内コンパートメントと関係があるシャペロン機能 糖タンパク質シャペロンは古典的なHSPが近づくのに限度があ るような細胞内コンパートメントで必要とされるかもしれな 
cess.

Support for this hypothesis comes from several studies of protein glycosylation and molecular folding within the ER, which is the principal organelle for initiating protein glycosylation. Considering the almost limitless sequence and structural variability possible for proteins that fold in the ER, it has been suggested that more than one type of molecular chaperone (e.g., $\mathrm{BiP}$ ) is required to bind various folding intermediates (Doms 1993). One possibility is an interactive role for $\mathrm{BiP}$ and protein glycosylation where BiP stabilizes the folding-competent and assembly-competent state of a polypeptide, and $N$-linked oligosaccharides are structural components that are necessary in the folding process after the polypeptide is released from BiP (Te Heesen 1994). Furthermore, in a non-aqueous membrane milieu (e.g., ER membrane), where classical HSPs have limited access, protein folding may require specialized glycoprotein chaperones, such as calnexin. It is now known that calnexin is part of a unique folding and quality control machinery in the ER that acts as a glycoprotein-specific chaperone (Hammond 1994a). Calnexin appears to recognize and bind partially glucose-trimmed carbohydrate side chains and requires $\mathrm{Ca}^{2+}$ as an essential co-factor for proper folding of certain secretory proteins (Lodish 1990). Furthermore, calnexin has been shown to cause the retention of free heavy chains of $\beta 2$-microglobulin within the ER, thereby, protecting them against rapid proteolytic degradation. Similarly, calnexin participates in quality control, transport, and efficient intracellular folding of $\mathrm{MHC}$ class I-peptide complexes (Jackson 1994). Calreticulin/PSG67, like calnexin, has been implicated in chaperone functions and showed both $\mathrm{Ca}^{2+}$ - and ATP-dependence (Nigam 1994), as discussed above. The ER chaperone functions, therefore, are sensitive to perturbations in calcium homeostasis, a notion that is further supported by the vigorous stress response which follows treatments with ionophores and leads to the retention of unfolded proteins within the ER (Lodish 1990). Calcium homeostasis is also challenged by heat stress, and causes a rise in intracellular $\mathrm{Ca}^{2+}$. Stress-induced glycosylation of $\mathrm{P}$ SG67/calreticulin, however, is independent of the rise in intracellular calcium because chelation of intracellular calcium with BAPTA did not prevent prompt glycosylation (Jethmalani 1984a).

Further evidence for glycoprotein-facilitated protein folding comes from a recent study (Hammond 1994b) where folding of the viral $G$ protein in the ER was observed to commence with initial binding of BiP to nascent proteins, which was then followed by calnexin binding to the more completely folded molecules. It is interesting to note that both efficient folding of the $G$ protein and retention of incompletely folded proteins did not occur without appropriate calnexin interactions (Hammond 1994b). Thus, glycoproteins have important physiological roles in normal cells and probably a related function
Wo

この仮説に対する支持は、いくつかのタンパク質のグリコ シル化とそのER内における分子の折り畳みの研究から得られて いる。ERはタンパク質のグリコシル化開始における重要なオル ガネラである。ERにおいて折り畳まれるタンパク質は、ほとん ど無限といえる配列と構造の変化を取り得ることから、いろい ろな折り畳み中間体に、一つ以上のタイプの分子シャペロン (BiP)が必要なことが示唆されている (Doms 1993)。一つの可能 性は、BiPとタンパク質のグリコシル化の相互作用の機能であ る。この場合、BiPは折り畳み準備と構造形成準備が完了した状 態のポリペプチドを安定化し、N-結合オリゴ糖はBiPからポリぺ プチドが遊離したあとの折り畳み過程に必要な構成成分である というものである(Te Heesen 1994)。さらに非水的な膜環境(たと えばER膜）においては古典的なHSPは限られた場所にしか近づ けないのでタンパク質の折り畳みには特別な糖タンパク質シャ ペロン(カルネクシンのような)が必要かもしれない。これまでに カルネクシンがERにおけるタンパク質の折り畳みと品質管理の 機構の一部として機能し、糖タンパク質特異的シャペロンとし て働くことが知られている (Hammond 1994a)。カルネクシンは 分泌タンパク質の正常な折り畳みに際して、(N-結合型糖鎖の生 合成過程で)部分的にグルコースが刈り込まれた糖鎖を認識して 結合すると考えられ、また、 $\mathrm{Ca}^{2+を}$ 必要とすることが知られて いる(Lodish 1990)。さらにカルネクシンはß-2ミクログロブリ ンの遊離の重鎖がER中に滞留するのを助け、それによって酵素 消化による速やかな分解を防いでいることが示された。また力 ルネクシンはMHCクラスI-ペプチド複合体の品質管理、運搬、 効果的な細胞内折り畳みなどに参与している(Jackson 1994)。力 ルレチクリン/P-SG67はカルネクシンと同様シャペロン機能が示 唆されていて、上記のように $\mathrm{Ca}^{2+}$ とATP双方に依存的であるこ とが示された(Nigam 1994)。ERシャペロンの機能はそれゆえカ ルシウムのホメオスタシスの微小変化に敏感である。このこと はイオノフォア処理により激しいストレス応答が起こること と、折り畳まれていない夕ンパク質がER内へ蓄積することによ り支持される概念である(Lodish 1990)。カルシウムホメオス夕 シスは熱ストレスによっても影響を受け、細胞内カルシウムの 上昇が起こる。しかしBAPTAによる細胞内カルシウムのキレー ションは敏速なグリコシル化を妨げないので、ストレスにより 誘導されるP-SG67/カルレチクリンのグリコシル化は、細胞内の カルシウムの上昇とは独立の現象である(Jethmalani 1984a)。

糖タンパク質によりタンパク折り畳みが助けられるという 考えは、ERにおけるウイルスGタンパク質の折り助みは合成淔 後のタンパク質にBiPが結合することにより開始され、その後よ り折り畳み過程が進んだ段階の分子にカルネクシンが結合する という、近年の研究によっても襄付けられている(Hammond 1994b)。Gタンパク質の効果的な折り畳みと不完全に折り畳ま れたタンパク質の $(\mathrm{ER} へ の)$ 蓄積が、いずれもカネクシンとの相 互作用無くしては起こらないことは興味深い(Hammond 1994b)。 このように糖タンパク質は正常な細胞において重要な生理的役 割を持ち、ストレスからの細胞の回復においてもそれに関連し 
during cellular recovery from stress. The observation of stress glycoproteins distributed throughout several subcellular compartments after heat stress (see above) is consistent with this concept.

\section{Stabilization, facilitated renaturation, and protection} against proteolysis. Stress-induced glycosylation facilitates protein renaturation and favors protein stabilization by blocking irreversible transition states.

This hypothesis derives support from several studies which demonstrate that protein glycosylation prevents not only protein aggregation, but is also important for maintenance of an active functional conformation. In yeast, glycosylation of invertase prevented its aggregation, and thereby facilitated its correct refolding (Schuelke 1988). In another study, hen egg white lysozyme, when expressed in a yeast system, gave rise to a hyperglycosylated form that was extremely heat stable with no evidence of coagulation under conditions that caused the wild-type lysozyme to irreversibly coagulate (Nakamura 1993).

The stabilization hypothesis is supported not only by hyperglycosylation studies leading to heat resistance, but also by hypoglycosylation studies that increase molecular heat sensitivity. The latter studies are based on specific deletions of glycosylation sites via oligonucleotide-directed mutagenesis. One such study used yeast acid phosphatase (AP) which has 12 potential $N$-glycosylation sequons (Asn-X-Ser/Thr), all of which are glycosylated in the wild type molecule (Riederer 1991). Systematic mutagenesis of glycosylation sequons yielded hypoglycosylation mutants that had severe defects in protein folding (Riederer 1991). The malfolded proteins were irreversibly retained in the ER and the fraction of retained AP protein correlated with the degree of hypoglycosylation. Further analysis of the hypoglycosylation mutants at lower temperatures indicated that reduced temperatures could compensate for the effect of reduced glycosylation. Reducing the temperature from $30^{\circ} \mathrm{C}$ to $15^{\circ} \mathrm{C}$ in the AP aglycone mutant, therefore, resulted in sufficient AP folding to measure enzymatic activity from unglycosylated AP (Riederer 1991). This demonstrated that enzymatic activity per se was not affected by either the amino acid exchange or the lack of glycan chains, but that glycosylation stabilized intermediate states of folded protein. Because protein folding is a critical step in the overall secretion process, glycosylation increased the efficiency of protein folding in a temperature-dependent manner and stabilized the folded protein against thermal denaturation. It was also noted that oligosaccharides at the C-terminus were more effective in mediating protein folding and stabilization, indicating that the formation of final tertiary structures was achieved only when the fully glycosylated protein is in the ER (Riederer 1991).

Not all glycosylation sites are necessarily identical in function. In hemagglutinin-neuraminidase, one specific oli-
た機能を持つ可能性がある。ストレス糖タンパク質が熱ストレ スを受けたあとにいくつかの細胞内コンパートメントに分布し て広がることは、この概念(上記)と一致する。

タンパク質を安定化し、再生を容易にし、酵素分解に対し保護

する機能 ストレスにより誘導されるグリコシル化はタンパク 質の再生を容易にし、不可逆的な遷移状態をブロックすること でタンパク質を安定化する

この仮説は、タンパク質のグリコシル化がタンパク質凝集 を阻止するだけでなく、活性型コンフォメーションの保持に重 要であることを示したいくつかの研究から支持を得ている。酵 母に扔いてはインベルターゼのグリコシル化はインベルターゼ の凝集を阻止し、それによってその正しい折り畳みを容易にす る (Schuelke 1988)。別の研究では、ニワトリ卵白リゾチームを 酵母の系で発現させると、過剩グリコシル化型を生じ、それは 非常に熱に安定で、野生型リゾチームの不可逆的凝集を起こす 条件下でも凝集を示さない (Nakamura 1993)。

安定化仮説は、熱抵抗性を与える過剩グリコシル化の研究 に支持されているだけでなく、分子の熱感受性を増大させる低 グリコシル化の研究によっても支持されている。後者の研究は オリゴヌクレオチド特異的突然変異誘発によるグリコシル化部 位の特異的除去にもとづいている。このような研究の一つは 12 の潜在的N-グリコシル化部位(Asn-X-Ser/Thr)を持つ酵母の酸性 ホスファターゼ(AP)を用いて行わ机た(Riederer 1991)。野生型分 子においては、この部位すべてがグリコシル化されている。 次々にグリコシル化部位を変異させることにより低グリコシル 化変異分子が得られたが、それらの分子はタンパク質折り畺み 機能に非常な欠損を持つことが明らかになった(Riederer 1991)。 折り畳み方の間違ったタンパク質は不可逆的にER中に蓄積し、 APタンパク質の蓄積はグリコシル化の度合いに対応していた。 低温における低グリコシル化変異株の分析により、低温が低グ リコシル化の効果を補うことが示された。APアグリコン変異株 の培養温度を $30^{\circ} \mathrm{C}$ から $15^{\circ} \mathrm{C}$ 一下げることにより、グリコシル化 していないAPからの酵素活性を測定できるくらい充分な量のAP が折り助まれた(Riederer 1991)。このことは酵素活性それ自身は アミノ酸残基の置換や、糖鎖の欠損による影響は受けず、グリ コシル化がタンパク質の折り畳み中間体を安定化することを示 している。タンパク質の折り畳みは全分泌過程の決定的な段階 であり、グリコシル化はタンパク質折り畳みの効率を温度依存 的に増大させるとともに、できあがったタンパク分子の熱安定 性を増大させる。C末端側のオリゴ糖鎖はタンパク質の折り畳み と安定化に他の部位のもの以上に寄与が大きいことから、最終 的な三次元構造の形成は完全にグリコシル化されたタンパク質 がERに存在するときにのみ起こることが示された(Riederer 1991)。

すべてのグリコシル化部位が必ずしも機能的に同一という わけではない。血球凝集ノイラミニダーゼに拧いては、ある一 
gosaccharide chain plays a major role in promoting correct folding, whereas another glycan chain, while not essential for initial folding, prevents aggregation of enzyme oligomers. Misfolded molecules in this system rapidly form disulfidelinked aggregates and are retained in the ER as stable complexes with $\mathrm{BiP}$; in contrast, wild-type proteins form specific and transient complexes with BiP during normal folding ( $\mathrm{Ng}$ 1990). In another study, it was shown that glycans at conserved positions synergistically promoted and stabilized protein conformation suitable for transport, and subsequently enhanced oligomeric assembly and folding rates for hemagglutinin (Roberts 1993).

Protein glycosylation may, or may not, be required for enzyme activity. In the case of lipase activity and enzyme secretion, glycosylation was essential for both folding of fully active enzyme and for secretion; in the presence of tunicamycin, cells produced an aglycone form of lipase that was both heat labile and showed less enzymatic activity (Abouakil 1993). Tunicamycin can also cause dramatically increased degradation of specific proteins (prohormone convertases, phosphotyrosine phosphatases) indicating proteolytic targeting and elimination of non-glycosylated isoforms (Benjannet 1993, Pulido 1992). In other systems, however, non-glycosylated homologs of catalytic glycoproteins suffered no functional decrement. This was the case for a truncated recombinant human lipase expressed in E. coli, where in spite of eliminating the glycosylation sequon, the heat stability and catalytic function was similar to that of the glycosylated enzyme (Downs 1994). These observations illustrate that specific glycosylation effects are dependent on the type of glycoprotein, the methods used for inhibition of glycosylation, and on the experimental endpoints used for comparing protein homologs.

Cellular proteolytic systems recognize specific protein conformational states, most commonly exposed hydrophobic regions, and eliminate these proteins. Proteolysis is costly to heat-stressed cells and requires re-synthesis to replace proteins at an energy cost that is generally higher than ATP-dependent protein renaturation. Protein denaturation, however, may be prevented by blocking critical transition states; conversely, renaturation can be achieved by prolonging other transition states that favor refolding with a return to the native protein conformation. The power of transition states is illustrated in the use of catalytic antibodies or "abzymes" that drive chemical reactions by stabilizing specific transition states (Suzuki 1994). Glycosylation may be a molecular means of favoring specific transition states. This area of glycobiology will probably become the focus of many future investigations.

\section{F. Conclusions}

We propose that mechanisms underlying the cellular stress response involve integrated and coordinated functions,
つのオリゴ糖鎖が正しい折り畳みを推進するのに主要な役割を 果たしている。また初期の折り畳みには必要ではない他の糖鎖 が酵素オリゴマーの凝集を防いでいる。間違って折り畳まれた 分子はSS結合を介した凝集物をすばやく形成し、BiPと安定な複 合体をつくってER中に蓄積する。それに対し野生型タンパク質 は、正常な折り畳み過程において、BiPと特異的で一過的な複合 体を形成する(Ng 1990)。また、別の研究から、保存された位置 にあるグリカン鎖それぞれが相乗的に働くことによって、輸送 に適したコンフォーメーションが安定化され、それによってこ の血球凝集素のオリゴマー形成と折り睍みの速度を増大させる ことが示されている(Roberts 1993)。

タンパク質のグリコシル化はその活性に必要かもしれない しそうでないかもしれない。リパーゼの活性とその分泌におい ては、グリコシル化は完全に活性のある酵素への折り畳みと酵 素の分泌の双方に不可欠であった。ツニカマイシン存在下では 細胞はアグリコン型のリパーゼを作ったが、この酵素は熱に不 安定で酵素活性も低かった(Abouakil 1993)。ツニカマイシンは また、特定のタンパク質(プロホルモン変換酵素、ホスフォチロ シンホスファターゼ)の分解を劇的に増大させる。このことは非 グリコシル化型イソフォームが酵素分解の標的となり、除去さ れていくことを示している(Benjannet 1993, Pulido 1992)。しかし ながら他の系では、非グリコシル化型の糖タンパク質酵素のホ モログは何ら機能の欠損を示さなかった。大腸菌において発現 された切断された(truncated)組み換えヒトリパーゼの場合がこれ で、グリコシル化部位を除去しても熱安定性と酵素機能はグリ コシル化された酵素のそれとほとんど同じであった(Downs 1994)。これらの観察は、個々の事例で認められたグリコシル化 の影響に関する知見が、糖タンパク質の型、グリコシル化の阻 害方法、タンパク質ホモログの比較に用いられた実験の限界な どに依存するものであることを示している。

細胞のタンパク質分解系は、タンパク質の特定のコンフォ メーション状態(普通は疎水的領域が露出した部分)を認識し、こ れらのタンパク質を除去する。タンパク質分解は、熱ストレス を受けている細胞にとっては高くつく過程である。除去された タンパク質を補うためには夕ンパク質を再合成することが必要 であり、この過程はATPに依存する高次構造再生系より一般的 に高いエネルギーコストがかかる。こ机に対して、タンパク質 の変性は、変性への決定的な遷移状態をブロックすることによ り阻止できる可能性がある。逆にいえば、未变性タンパク質コ ンフォメーションへ戻るための折り畳みに有利な遷移状態を長 引かせることによりコンフォメーションの再生をおこなうこと ができる。このような遷移状態の重要性は、酵素抗体(abzyme) の作用において明らかにされている(Suzuki 1994)。酵素抗体は 特定の遷移状態を安定化することにより化学反応を推進する。 グリコシル化は、ある特定の遷移状態をとらせるための分子的 手段であるのかもしれない。糖鎖生物学のこの分野は、将来の 多くの研究の焦点となる可能性が大きい。

\section{F. 結論}

我々は、細胞のストレス応答の基になるメカニズムはよく 
including the activity of both "classical" HSPs and stress-induced protein glycosylation. In heat-stressed cells, protein glycosylation occurs both immediately ("prompt" glycosylation) and later when cells recover in concurrence with the development of thermotolerance. Specific functions for stressinduced protein glycosylation in vivo have not yet been confirmed, although it is clearly evident that homologs of particular stress glycoproteins do exist in cells of different origin and species. The recent identification of several stress glycoproteins and new information about the functional significance of glycosylation under non-stress conditions, leads us to hypothesize that stress glycosylation serves as a primary mechanism for preventing aggregation of proteins when their hydrophobic regions are uncovered. Since heat-induced protein aggregation is often irreversible and is accompanied by illegitimate disulfide bond formation, we hypothesize that protein glycosylation can also confer structural stability and facilitated renaturation to stress-denatured cellular proteins.

These two major elements of the stress response (HSPs and stress glycosylation) may be complementary (inhibiting aggregation, stabilization, and renaturation) and synergistic in conferring stress resistance to pre-stressed cells. Although each element of this mechanism has its own principal and independent function, built-in redundancy probably allows overlap between primary and secondary physiological functions of these two stress response elements. Our hypothesis further predicts that overexpression of either of the two stress response elements (HSPs or glycosylation) can provide partial expression of stress resistance.

\section{Acknowledgments}

This work was supported in parts by PHS Grant CA33405, awarded by the National Cancer Institute, DHHS.
調和し統合されたものであり、その中には“古典的”なHSPsとス トレスにより誘導されるタンパク質のグリコシル化の両者の機 能が関与していると提案したい。熱ストレスを受けた細胞にお けるタンパク質のグリコシル化には、即座に起こるもの(“敏速 な”グリコシル化)と、その後に細胞が熱許容性の獲得を伴って 回復するときに起こるものとがある。特定のストレス(応答)糖夕 ンパク質のホモログが異なる種や異なる起源の細胞に存在する ことは明白であるが、このストレスにより誘導されるタンパク 質のグリコシル化の in vivoにおける機能はまだ明確になってい ない。近年同定されたいくつかのストレス糖タンパク質と、非 ストレス条件下でのグリコシル化の機能的重要性に関する新た な情報から、我々は、ストレスに応答したグリコシル化が夕ン パク質の疎水部分が露出した時に起こる凝集を防ぐ第一のメカ ニズムとして働くという仮説をたてた。熱により起こるタンパ ク質の凝集は非可逆的で、不特定のSS結合形成を伴うことが多 いため、我々は夕ンパク質のグリコシル化が構造を安定化し、 ストレスにより変性した細胞のタンパク質を再生するのを助け るのだという仮説をたてた。

これらの二つの主なストレス応答要因(HSPとストレス応答 グリコシル化)はストレスにさらされた細胞に耐性を与える上で 相補的かつ相乗的に作用するのであろう(凝集の阻止、安定化、 再生)。このメカニズムの各構成因子はそれぞれ独自の主要な機 能を持つが、この二種類の因子がそれぞれ重複する性質をもっ ているので、恐らくそれらの生理的機能が重なり合うことに なっているのだろう。我々の仮説は、さらにこれらの二つのス トレス応答因子(HSPまたはグリコシル化)のどちらか一方の過剩 発現が、ストレス抵抗性を部分的に発現させることができるこ とを予測させるものである。

農水省農業生物資源研究所

伊藤 ユキ訳

\section{References}

Abouakil, N., Mas, E., Bruneau, N., Benajiba, A., and Lombardo, D. (1993) J. Biol. Chem. 268, 25755-25763

Becker, J., and Craig, E.A. (1994) Eur. J. Biochem. 219, 11-23

Benjannet, S., Rondeau, N., Paquet, L., Boudreault, A., Lazure, C., Chretien, M., and Seidah, N.G. (1993) Biochem. J. 294, 735-743

Bergeron, J.J.M., Brenner, M.B., Thomas, D.Y., and Williams, D.B. (1994) Trends Biochem. Sci. 19, 124-128

Cheng, L, Kirk, N., and Piper, P.W. (1993) Biochem. Biophys. Res. Commun. 195, 201-207

Clarke, E.P., Cates, G.A., Ball, E.H., and Sanwal, B.D. (1991) J. Biol. Chem. 266, 17230-17235

DeVirgilio, C., Simmen, U., Hottiger, T., Boller, T., and Wiemken, A. (1990) FEBS Lett. 273, 107-110

Doms, R.W., Lamb, R.A., Rose, J.K., and Helenius, A. (1993) Virology 193, 545-562

Dorner, A.J., Wasley, L.C., Raney, P., Haugejorden, S., Green, M., and Kaufman, R.J. (1990) J. Biol. Chem. 265, 22029-22034

Downs, D., Xu, Y.-Y., Tang, J., and Wang, C.-S. (1994) Biochemistry 33, 7979-7985

Freedman, R. B. (1989) Cell 57, 1069-1072

Hammond, C., and Helenius, A. (1994b) Science 266, 456-458

Hammond, C, Braakman, I., and Helenius, A. (1994a) Proc. Natl. Acad. Sci. USA 91, 913-917

Hartl, F.U., Hlodan, R., and Langer, T. (1994) Trends Biochem. Sci. 19, 20-25

Henle, K.J. (1981) Radiat. Res. 88, 392-402

Henle, K.J. (1987) In Thermotolerance, Vol. I, K.J. Henle, ed., CRC Press, Boca Raton, FL, pp. 13-71

Henle, K.J. (1987b) In Thermotolerance,Vol. I, K.J .Henle, ed., CRC Press, Boca Raton, FL, pp.127-143

Henle, K.J., and Dethlefsen, L.A, (1978) Cancer Res. 38, 1843-1851

Henle, K.J., and Nagle, W.A. (1991) Exp. Cell Res. 196, 184-191

Henle, K.J., Jethmalani, S.M., Li, L., and Li, G.C. (1995) Submitted. 
Henle, K.J., Kaushal, G.P., Nagle, W.A., and Nolen, G.T, (1993) Exp. Cell Res. 207, 245-251

Henle, K.J., Monson, T.P., and Stone, A. (1990) J. Cell. Physiol. 142, 372-378

Henle, K.J., Monson, T.P., Nagle, W.A., and Moss, A.J. (1985) Int. J. Hyperthermia 1, 371-382

Henle, K.J., Nagle, W.A., Bedford, J.S., and Harvey, W.F. (1990b) J. Cell Sci. 95, 555-561

Henle, K.J., Nagle, W.A., Moss, A.J., and Herman, T.S. (1982) Radiat. Res. 92, 445-451, 1982

Henle, K.J., Nagle, W.A., Norris, J.S., and Moss, A.J. (1988) Int. J. Radiat. Biol. 53, 839-847

Henle, K.J., Stone, A., and Chatterjee, S.K. (1988b) Cancer Res. 48, 5717-5721

Henle, K.J., Wang, S.-Y., Nagle, W.A., and Lumpkin, C.K. (1994) Exp. Cell Res. 210, 185-191

Hirayoshi, K., Kudo, H., Takechi, H., Nakai, A., Iwamatsu, A., Yamada, K.M., and Nagata, K. (1991) Mol. Cell Biol. 11, 4036-4044

Hottiger, T., De Virgilio, C., Bell, W., Boller, T., and Wiemken, A. (1992) Eur. J. Biochem. 210, 125-132

Hottiger, T., De Virgilio, C., Hall, M.N., Boller, T., and Wiemken, A. (1994) Eur. J. Biochem. 219, 187-193

Jackson, M.R., Cohen-Doyle, M.F., Peterson, P.A., and Williams, D.B. (1994) Science 263, 384-387

Jethmalani, S.M., and Henle, K.J. (1994a) Biochem. Biophys. Res. Commun. 205, 780-787

Jethmalani, S.M., Henle, K.J., and Kaushal, G.P. (1994b) J. Biol. Chem. 269, 23603-23609

Kern, G., Schmidt, M., Buchner, J., and Jaenicke, R. (1992) FEBS Lett. 305, 203-205

Laszlo, A. (1988) Int. J. Hyperthermia 4, 513-526

Laszlo, A. (1992) Cell Prolif. 25, 59-87

Lee, A.S. (1992) Curr. Opin. Cell Biol. 4, 267-273

Lee, Y.J., and Dewey, W.C. (1988) Cell. Physiol. 135, 397-406

Li, G.C., Li, L., Liu, Y.-K., Mak, J.Y.,Chen, L., and Lee, W.M.F. (1991) Proc. Natl. Acad. Sci. USA 88, 1681-1685

Lodish, H.F., and Kong, N. (1990) J. Biol. Chem. 265, 10893-10899

Lund, P. (1994) Bioessays 16, 229-231

Marquardt, T., and Helenius, A. (1992) J. Cell Biol. 117, 505-513

Michalak, M., Milner, R.E., Burns, K., and Opas, M. (1992) Biochem. J. 285, 681-692

Morimoto, R.I. (1993) Science 259, 1409-1410

Nakamura, S., Takasaki, H., Kobayashi, K., and Kato, A. (1993) J. Biol. Chem. 268, 12706-12712

Natsume, T., Koide, T., Yokota, S.-I., Hirayoshi, K., and Nagata, K. (1994) J. Biol. Chem. 269, 31224-31228

Ng, D.T.W., Hiebert, S.W., and Lamb, R.A. (1990) Mol. Cell. Biol. 10, 1989-2001

Niewiarowska, A., Caltabiano, M.M., Bailey, D.S., Poste, G., and Greig, R.G., (1987) J. Biol. Chem. 262, 14815-14820

Nigam, S.K., Goldberg, A.L., Ho, S., Rohde, M.F., Bush, K.T., and Sherman, M.Y. (1994) J. Biol. Chem. 269, $1744-1749$

Ou, W.-J., Cameron, P.H., Thomas, D.Y., and Bergeron, J.J.M. (1993) Nature 364, 771-776

Parsell, D.A., and Lindquist, S. (1993) Ann. Rev. Genet. 27, 437-496

Parsell, D.A., Kowal, A.S., Singer, M.A., and Lindquist, S. (1994) Nature 372, 475-478

Parsell, D.A., Taulien, J., and Lindquist, S. (1993b) Philos. Trans. R. Soc. Lond. B Biol. Sci. 339, 279-285

Piper, P.W. (1993) FEMS Microbiol. Rev. 11, 339-355

Potempa, J., Korzus, E., and Travis, J., (1994) J. Biol. Chem. 269, 15957-15960

Pulido, R., and Sanchez-Madrid, F. (1992) Eur. J. Immunol. 22, 463-468

Qu, D., Mazzarella, R.A., and Green, M. (1994) DNA Cell. Biol. 13, 117-124

Riederer, M.A., and Hinnen, A. (1991) J. Bacteriol. 173, 3539-3546

Roberts, P.C., Garten, W., and Klenk, H.-D. (1993) J. Virol. 67, 3048-3060

Schlesinger, M.J. (1994) Pediatr. Res. 36, 1-6

Schuelke, N., and Schmid, F.X. (1988) J. Biol. Chem. 263, 8832-8837

Stevenson, M.A., and Calderwood, S.K. (1990) Mol. Cell. Biol. 10, 1234-1238

Stuart, R.A., Cyr, D.M., Craig, E.A., and Neupert, W. (1994) Trends. Biochem. Sci. 19, 87-92

Suzuki, H. (1994) J. Biochem. 115, 623-628

Takechi, H., Hirayoshi, K., Nakai, A., Kudo, H., Saga, S., and Nagata, K. (1992) Eur. J. Biochem. 206, 323-329

Takechi, H., Hosokawa, N., Hirayoshi, K., and Nagata, K. (1994) Mol. Cell. Biol. 14, 567-575

Te Heesen, S., and Aebi, M., (1994) Eur. J. Biochem. 222, 631-637

Todd, M.J., Viitanen, P.V., and Lorimer, G.H. (1994) Science 265, 659-666

Wang, S.-Y., and Gudas, L.J. (1990) J. Biol. Chem. 265, 15818-15822

Wang, S.-Y.(1994) J. Biol. Chem. 269, 607-613

VanWhy, S.K., Mann, A.S., Thulin, G., Zhu, X.-H., Kashgarian, M., and Siegel, N.J. (1994) J. Clin. Invest. 94, 1518-1523

Received on March 2, 1995, accepted on March 5,1995 